\title{
Dinamika Populasi Wereng Punggung Putih, Sogatella furcifera Stål (Hemiptera: Delphacidae) Di Jawa Tengah
}

\author{
I NYOMAN WIDIARTA, E.S. WIJAYA DAN HIROICHI SAWADA
}

Balai Besar Penelitian Tanaman Padi

Jl. Raya No. 9 Sukamandi, Subang

(diterima Mei 2004, disetujui Agustus 2005)

\begin{abstract}
Population Dynamic of The Whitebacked Planthopper, Sogatella furcifera Stål (Hemiptera: Delphacidae) In Central Java. I Nyoman Widiarta, E.S. Wijaya dan Hiroichi Sawada. A field study was conducted at paddy fields in Petarukan and Pekalongan regencies of Central Java province during wet season crop 1989/90 and 1990/91 to elucidate population dynamic of whitebacked planthopper, Sogatella furcifera Stål. Seven and three observation fields were set up in $1989 / 90$ and the 1990/91, respectively. Cisadane rice cultivar was transplanted following the usual farmer's parctices except that no pesticide was applied. The population of the whitebacked planthopper and the brown planthopper, (Nilaparvata lugens Stål) were sampled by using an insect suction catcher, a farmcop. Identification of generation was based on thermal constant required by the whitebacked planthopper to complete one generation and mean population density was calculated by graphical method. Two distinct seasonal population growth patterns were identified. The population with short population growth pattern completed four generations in one crop season in which their population density increased consecutively in two generations since immigrant generation, and thereafter decreased. The population with long population growth completed five generations in one crop season in which their population density increased consecutively in three generations, and thereafter decreased. The density of brachiptera adults determined $90 \%$ of the total population density. The proportion of brachiptera adults were not correlated with large nymphal density in both vegetative and generative stages of rice. The proportion of brachiptera adults showed significant negative linear regression with population density of the brown planthopper. Therefore, interspesific competition determined the proportion of wingform and population dynamics of the whitebacked planthopper.
\end{abstract}

KEY WORDS: Sogatella furcifera, population dynamics, brachiptera form

\section{PENDAHULUAN}

Wereng punggung putih, Sogatella furcifera Stål (Hemiptera: Delphacidae), menempati relung ekologi (niche) yang sama dengan wereng coklat, (Nilaparvata lugens Stål) pada tanaman padi. Wereng coklat sendiri dikenal sebagai penyebab mati kering (bopperburn) pada tanaman padi akibat isapan cairan tanaman oleh individu wereng coklat dalam jumlah banyak. Wereng coklat dapat mencapai kepadatan populasi per rumpun yang tinggi di Asia Pasifik setelah diadopsinya teknologi Revolusi Hijau (Dyck et al. 
1979). Hopperburn akibat wereng coklat terjadi secara luas di Indonesia pada periode 1970 sampai awal tahun 1980 (Oka 1982). Wereng punggung putih di Jepang akhir-akhir ini dilaporkan juga menyebabkan hopperburn pada tanaman padi disepanjang pantai utara Pulau Honshu (Murai et al. 1986; Matsumura 1991). Di pantai utara Jawa Barat kepadatan populasi wereng punggung putih juga dilaporkan meningkat sejak musim tanam 2000 (Baehaki \& Rifki 2002).

Populasi wereng punggung putih yang berkembang pada musim tanam padi di Jepang berasal dari populasi imigran dari Cina. Akhir-akhir ini kepadatan populasi imigran yang sampai di Jepang meningkat (Watanabe et al. 1994). Peningkatan kepadatan populasi imigran disebabkan oleh meluasnya areal pertanaman padi hibrida di Cina. Padi hibrida mulai ditanam di Cina pada tahun 1976. Luas pertanamannya meningkat pesat hingga mencapai 50\% areal pertanaman pada tahun 1990 . Meluasnya areal tanam padi hibrida di Cina telah menyebabkan terjadinya ledakan kepadatan populasi wereng punggung putih karena pada padi hibrida indika seperti Shanyou 63, aktivitas mengisap dan sintasan telur wereng punggung putih lebih tinggi dibandingkan dengan pada padi inbrida japonika Chenjiang 06 (Sogawa 1999).

Produksi padi Indonesia semakin dituntut untuk lebih ditingkatkan agar dapat mengimbangi kebutuhan beras yang semakin meningkat akibat pertum- buhan jumlah penduduk yang masih terus terjadi dan konsumsi perkapita yang masih tinggi. Produktivitas padi inbrida telah mengalami stagnasi karena keterbatasan potensi genetik. Untuk memperbaiki produktivitas padi, salah satu jalan yang ditempuh adalah dengan memanfaatkan keunggulan heterosis pada padi hibrida. Pada tahun 2002 telah dilepas empat varietas padi hibrida hasil rakitan dalam negeri di Balai Penelitian Tanaman Padi (Balitpa 2002). Dengan demikian, luas areal penanaman padi hibrida pada masa yang akan datang akan semakin luas. Perluasan areal tanam padi hibrida dipromosikan melalui kegiatan Peningkatan Produktivitas Padi Terpadu yang dimulai pada tahun 2002 (Suwarno et al. 2002). Belajar dari pengalaman Jepang dan Cina sebagai dampak dari meluasnya areal tanam padi hibrida di Cina, masalah wereng punggung putih diperkirakan akan semakin meningkat.

Dinamika populasi wereng coklat telah dipahami melalui laporan oleh Sawada et al. (1993), sedangkan pemahaman pola dasar pertumbuhan populasi wereng punggung putih saat ini masih kurang. Penelitian ini dilaksanakan untuk mempelajari dinamika populasi wereng punggung putih dan faktorfaktor yang mempengaruhinya termasuk kompetisi antar spesies antara wereng punggung putih dan wereng coklat pada padi inbrida. Informasi mengenai dinamika populasi wereng punggung putih mendesak untuk dipublikasikan guna 
mengetahui dinamika populasinya sebelum padi hibrida ditanam luas.

\section{BAHAN DAN METODE}

\section{Pelaksanaan Percobaan}

Penelitian dilakukan di Jawa Tengah pada musim tanam musim hujan (MH) 1989/90 dan 1990/91. Varietas rentan wereng Cisadane ditanam pada tujuh lokasi pada MH 1989/90, yaitu dua lokasi di Laboratorium Lapangan Petarukan, dan lima lokasi di sawah milik petani di Pekalongan. Pada $\mathrm{MH}$ 1990/91, varietas padi yang sama ditanam pada tiga lokasi, yaitu satu lokasi di Laboratorium Lapangan Petarukan dan dua lokasi di sawah milik petani di Pekalongan. Bibit padi ditanam pindah dan selanjutnya budi daya padi mengikuti cara budidaya petani setempat, kecuali tanpa aplikasi insektisida. Bibit padi umur 21 hari setelah sebar (HSS) ditanam pada 10 petak $(10 \mathrm{~m} \times 10 \mathrm{~m})$ dengan jarak tanam $25 \mathrm{~cm}$ x $25 \mathrm{~cm}$ pada setiap kali tanam. Dosis pupuk yang diaplikasikan adalah $300 \mathrm{~kg}$ urea/ha, 100 $\mathrm{kg}$ TSP/ha dan $50 \mathrm{~kg} \mathrm{KCl} / \mathrm{ha}$. Pemupukan urea dilakukan tiga kali aplikasi masing-masing $100 \mathrm{~kg} / \mathrm{ha}$. Sebagai pupuk dasar diaplikasikan $100 \mathrm{~kg}$ urea/ha dan seluruh pupuk TSP dan $\mathrm{KCl}$. Gulma disiang secara manual dengan cara mencabut dengan tangan kemudian dibenamkan ke dalam tanah.

Kepadatan populasi $S$. furcifera dan artropoda lainnya diamati dengan menggunakan alat pengisap serangga farmcop (Carino et al. 1979) seminggu sekali seperti yang telah dilakukan oleh Widiarta et al. (1990). Rumpun contoh atau satuan contoh dikurung dengan kurungan plastik, dan serangga yang terperangkap di dalamnya diisap seluruh nya. Ukuran kurungan plastik disesuaikan dengan pertumbuhan tanaman padi. Kurungan lebar tetapi pendek yang ukuran $55 \mathrm{~cm} \times 55 \mathrm{~cm}$ bagian atas dan $40 \mathrm{~cm} \times 40 \mathrm{~cm}$ bagian bawah dengan tinggi $60 \mathrm{~cm}$ digunakan untuk mengurung empat rumpun tanaman padi saat tanaman umur 1-8 minggu setelah tanam (MST). Pada periode tersebut, satu unit sampel terdiri dari empat rumpun, setiap petak diamati lima unit sampel. Kurungan lebih sempit tetapi lebih tinggi dengan ukuran atas $40 \mathrm{~cm} \times 40$ $\mathrm{cm}$, bagian bawah $30 \mathrm{~cm} \times 30 \mathrm{~cm}$ dengan tinggi $120 \mathrm{~cm}$ digunakan untuk mengurung satu rumpun tanaman padi, mulai saat tanaman umur 9 MST sampai seminggu sebelum panen. Dengan demikian, satu unit sampel terdiri dari satu rumpun tanaman. Bagian atas kurungan ditutup dengan kain warna hitam untuk mencegah serangga keluar dari kurungan. Artropoda yang terisap diawetkan dalam alkohol 70\%, kemudian diidentifikasi jenis dan dihitung jumlahnya di laboratorium. Penentuan lokasi unit sampel dilakukan dengan menggunakan bilangan acak. Pengamatan dengan farmcop hanya dilakukan sekali untuk setiap unit sampel. Pengamatan visual dilakukan pada tengah minggu antara dua waktu pengamatan dengan farmcop. Berdasarkan hasil survei pendahuluan tentang kepadatan populasi 
per rumpun dan pola penyebaran ruang wereng punggung putih, dan agar data dapat digunakan untuk analisis dinamika populasi, maka disusun rencana pengamatan yang menghasilkan kesalahan pengamatan kurang dari 20\% (Kuno 1991) dengan menyesuaikan jumlah rumpun tanaman yang diamati. Jumlah rumpun padi yang diamati secara visual bervariasi antara 360 dan 600 rumpun setiap lokasi dan setiap kali pengamatan, bergantung pada kepadatan populasi dan fase pertumbuhan tanaman. Pada pengamatan dengan farmcop, jumlah rumpun yang diamati saat tanaman umur 1-8 MST berjumlah 200 rumpun, sedangkan pada saat tanaman umur 9 MST sampai menjelang panen diamati 50 rumpun. Rumpun tanaman yang diamati visual ditentukan secara sistematis berselang satu rumpun.

\section{Identifikasi Generasi dan Kepadatan Populasi}

Identifikasi generasi dilakukan mengikuti prosedur yang dipergunakan oleh Widiarta et al. (1990), dengan memetakan rataan individu per rumpun pada kumulatif kebutuhan panas efektif, yaitu kumulatif suhu harian di atas ambang suhu $12^{\circ} \mathrm{C}$ yang diperlukan untuk melengkapi pertumbuhan $S$. furcifera (Kuno 1968). Perhitungan generasi imigran dimulai seminggu sebelum individu wereng punggung putih ditemukan sampai puncak periode peneluran betina. Kebutuhan panas untuk satu generasi $S$. furcifera yang dipakai sebagai batas satu generasi adalah 345 derajat-hari (Kuno 1968). Demi kemudahan, 345 derajat-hari bagian pertama disebut GO, bagian berikutnya disebut G1, dan seterusnya. Kepadatan populasi satu generasi dihitung dengan menggunakan metode grafik. Luas areal di bawah garis kepadatan populasi per rumpun dalam satu gererasi dihitung $(\mathrm{L})$. Kepadatan populasi satu generasi dihitung dengan menggunakan rumus $\mathrm{L} / 345$.

\section{HASIL DAN PEMBAHASAN}

\section{Generasi Imigran}

Populasi generasi imigran wereng punggung putih ditemukan seminggu lebih awal dari pada wereng coklat (Tabel 1). Dari 200 rumpun ditemukan rata-rata tiga ekor wereng punggung putih, lebih sedikit dibandingkan dengan wereng coklat yang ditemukan dari jumlah rumpun yang sama yang mencapai rata-rata empat ekor meskipun jumlah nya tidak berbeda nyata. Variasi waktu datangnya generasi imigran wereng punggung putih lebih kecil daripada wereng coklat. Kepadatan populasi imigran wereng punggung putih di Jatisari,Karawang di Pantai Utara (Pantura) Jawa Barat berbeda dengan di Petarukan, Pekalongan (Pantura Jawa Tengah). Kepadatan populasi imigran wereng punggung putih di Jatisari jauh lebih tinggi daripada kepadatan populasi imigran wereng coklat (Widiarta, 1995). Variasi waktu datangnya imigran wereng punggung putih yang kecil kemungkinan disebabkan oleh 
Tabel 1. Kepadatan populasi dan waktu kedatangan wereng imigran

\begin{tabular}{|c|c|c|c|c|c|}
\hline \multirow[b]{2}{*}{ Musim tanam } & \multirow[b]{2}{*}{ Lokasi } & \multicolumn{2}{|c|}{ Wereng Punggung Putih } & \multicolumn{2}{|c|}{ Wereng Coklat } \\
\hline & & $\begin{array}{l}\text { Waktu } \\
(\mathrm{MST})^{1)}\end{array}$ & $\begin{array}{c}\text { Populasi } \\
\text { (per } 200 \mathrm{rp}^{2)} \text { ) }\end{array}$ & $\begin{array}{l}\text { Waktu } \\
(\mathrm{MST})^{1)}\end{array}$ & $\begin{array}{c}\text { Populasi } \\
\left(\text { per } 200 \mathrm{rp}^{2)}\right)\end{array}$ \\
\hline \multirow[t]{7}{*}{$\overline{1989 / 90}$} & 1 & 2,5 & 1 & 5,0 & 3 \\
\hline & 2 & 1,0 & 1 & 2,5 & 1 \\
\hline & 3 & 2,0 & 2 & 1,5 & 1 \\
\hline & 4 & 1,0 & 4 & 1,0 & 2 \\
\hline & 5 & 1,0 & 1 & 4,5 & 2 \\
\hline & 6 & 1,5 & 1 & 1,5 & 2 \\
\hline & 7 & 1,0 & 3 & 1,5 & 2 \\
\hline \multirow[t]{3}{*}{$1990 / 91$} & 8 & 1,0 & 5 & 1,5 & 20 \\
\hline & 9 & 1,0 & 7 & 1,5 & 5 \\
\hline & 10 & 1,0 & 1 & 1,5 & 2 \\
\hline Rata-rata & & 1,3 & 2,6 & 2,1 & 4 \\
\hline $\begin{array}{l}\text { Simpangan } \\
\text { baku }\end{array}$ & & 0,5 & 2,1 & 1,5 & 5,8 \\
\hline
\end{tabular}

Keterangan : ${ }^{1)}$ MST: minggu setelah tanam; ${ }^{2)}$ rp: rumpun

Tabel 2. Kepadatan populasi dan kecepatan pertumbuhan kepadatan populasi wereng punggung putih

\begin{tabular}{|c|c|c|c|c|c|c|c|c|c|c|}
\hline \multirow{2}{*}{$\begin{array}{l}\text { Musim } \\
\text { Tanam } \\
\end{array}$} & \multirow{2}{*}{ Lokasi } & \multicolumn{5}{|c|}{ Kepadatan populasi (log) } & \multicolumn{4}{|c|}{ Kecepatan pertumbuhan (log) } \\
\hline & & G0 & G1 & G2 & G3 & G4 & $\mathrm{r} 1$ & r2 & r3 & r4 \\
\hline \multirow[t]{4}{*}{$1989 / 90$} & 1 & $-1,401$ & $-0,259$ & 0,211 & $-0,762$ & - & 1,142 & 0,470 & $-0,972$ & - \\
\hline & 2 & $-1,300$ & $-0,528$ & $-0,485$ & $-1,726$ & - & 0,772 & 0,043 & $-1,241$ & - \\
\hline & 3 & $-0,958$ & 0,710 & 1,008 & $-0,781$ & - & 1,668 & 0,298 & $-1,789$ & - \\
\hline & 4 & $-1,061$ & $-0,327$ & $-0,212$ & $-0,096$ & - & 0,734 & 0,115 & 0,116 & - \\
\hline \multirow[t]{3}{*}{$1990 / 91$} & 8 & $-0,926$ & 0,095 & 0,383 & $-0,036$ & - & 1,021 & 0,288 & $-0,420$ & - \\
\hline & 9 & $-0,876$ & $-0,014$ & $-0,820$ & $-1,967$ & - & 0,863 & $-0,807$ & $-1,146$ & - \\
\hline & 10 & $-1,415$ & $-0,429$ & 0,388 & 0,048 & - & 0,985 & 0,818 & $-0,340$ & - \\
\hline Rata-rata & & $-0,986$ & $-0,072$ & 0,107 & $-0,582$ & - & 0,911 & 0,185 & $-0,672$ & - \\
\hline Varian & & 0,054 & 0,178 & 0,380 & 0,668 & - & 0,101 & 0,252 & 0,419 & - \\
\hline \multirow[t]{3}{*}{$1989 / 90$} & 5 & $-2,201$ & $-1,095$ & $-0,474$ & $-0,325$ & $-1,193$ & 1,106 & 0,621 & 0,148 & $-0,868$ \\
\hline & 6 & $-1,421$ & $-0,405$ & $-0,093$ & $-0,089$ & $-0,761$ & 1,017 & 0,312 & 0,004 & $-0,672$ \\
\hline & 7 & $-1,281$ & $-0,599$ & $-0,309$ & $-0,197$ & $-1,292$ & 0,682 & 0,290 & 0,112 & $-1,095$ \\
\hline Rata-rata & & $-1,635$ & $-0,699$ & $-0,292$ & $-0,204$ & $-1,082$ & 0,935 & 0,408 & 0,088 & $-0,879$ \\
\hline varian & & 0,245 & 0,127 & 0,036 & 0,014 & 0,080 & 0,049 & 0,034 & 0,006 & 0,045 \\
\hline
\end{tabular}

lebih luasnya jenis tanaman inang dingkan dengan wereng coklat yang wereng punggung putih. Wereng hanya dapat berkembang biak pada punggung putih dapat hidup pada gulma tanaman padi.

(Reissig et al., 1986) selain padi, diban- 
Fenomena Fluktuasi Populasi Musiman

Dari 10 lokasi hasil pengamatan dapat dibedakan dua pola fluktuasi kepadatan populasi, yaitu populasi dengan masa keberadaan pendek (kurang dari 15 MST) disebut pola pendek (Gambar 1), dan populasi dengan masa keberadaan panjang (sampai 15 MST) disebut pola panjang (Gambar 2). Dari tujuh lokasi pengamatan pada MH 1989/90, diketahui bahwa empat termasuk pola pendek dan tiga termasuk pola panjang, sedangkan dari tiga lokasi pengamatan pada MH 1990/91, ketiganya termasuk pola pendek.

Dari populasi pola pendek berhasil diidentifikasi empat generasi, sedangkan dari populasi dengan pola panjang teridentifikasi lima generasi (Tabel 2). Rata-rata kepadatan populasi imigran (G0) pada populasi pola pendek dalam logaritme mencapai -0,986, dan lebih tinggi daripada populasi pola panjang yang hanya mencapai $-1,635$. Kepadatan populasi tertinggi pada populasi pola pendek terjadi pada G2 dengan rata-rata kepadatan populasi 0,107, sedangkan pada populasi pola panjang, kepadatan populasi tertinggi terjadi pada G3 dengan rata-rata kepadatan populasi -0,204. Kecepatan pertumbuhan populasi tertinggi terjadi pada r1 (G0 ke G1) pada kedua pola populasi Perbedaan pola pertumbuhan populasi antara populasi pola pendek dan pola panjang dengan jelas dapat dilihat pada Gambar 3.
Meskipun rata-rata kepadatan populasi G0 pada pola populasi panjang lebih rendah daripada populasi pola pendek, kepadatan populasi per generasi terus meningkat hingga tiga generasi sampai G3, dan pada G4 kepadatan populasi menurun. Pada pola pendek kepadatan populasi per generasi hanya meningkat sampai dua generasi hingga G2, dan pada G3 kepadatan populasi telah menurun.

Pola pertumbuhan populasi pendek menyerupai pola pertumbuhan populasi wereng punggung putih di daerah beriklim empat musim di Kyushu bagian selatan Jepang (Kuno 1968) maupun di Hokuriku bagian utara Jepang (Matsumura 1996b), akan tetapi pola pertumbuhan populasi panjang adalah unik untuk populasi daerah tropika di Jawa Tengah.

\section{Peran Wereng Sayap Pendek (Brakiptera)}

Imago wereng punggung putih memiliki dua bentuk sayap yang berbeda (wing dimorphism), yaitu imago bersayap panjang (makroptera) dan imago bersayap pendek (brakiptera). Kepadatan populasi brakiptera per generasi berkorelasi positif dengan koefisien determinan 90\% terhadap kepadatan populasi per generasi (Gambar 4). Kepadatan populasi brakiptera 90\% menentukan kepadatan populasi total wereng punggung putih. Keperidian awal, yaitu jumlah telur yang diletakkan pada minggu-minggu awal setelah ganti kulit men- 

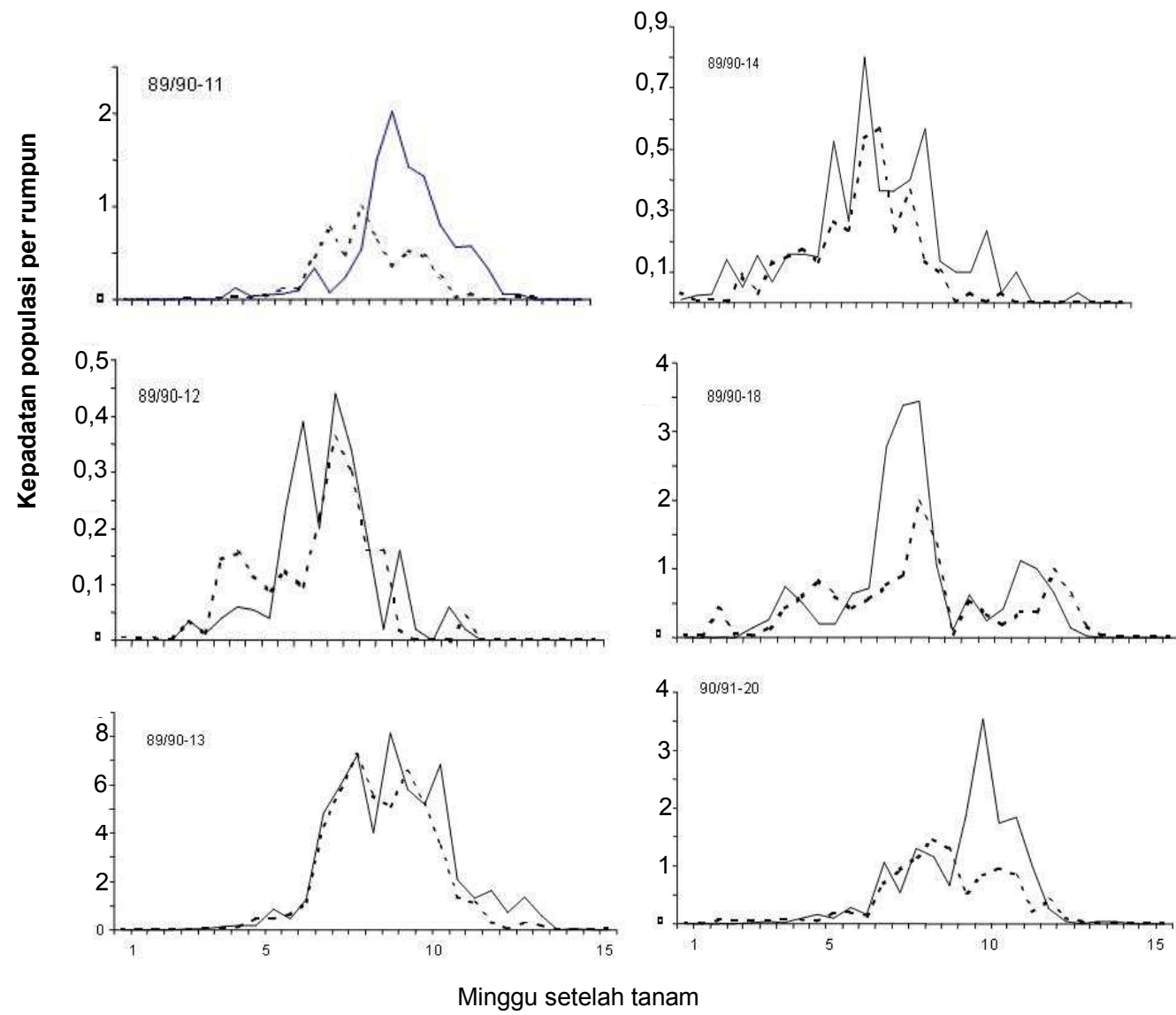

Gambar 1. Fluktuasi populasi imago (garis putus-putus) dan nimfa besar (garis) wereng punggung putih pada beberapa pengamatan dengan keberadaan populasi yang pendek

jadi imago pada brakiptera lebih tinggi dibandingkan dengan makroptera (Matsumura 1994). Pada kebanyakan famili Delphacidae yang menunjukkan dua bentuk sayap, yaitu brakiptera dan makroptera, fenomena tersebut merupakan konflik (trade off) antara kemampuan reproduksi dan pemencaran Brakiptera yang tidak dapat terbang umumnya lebih produktif, sebaliknya makroptera yang mampu terbang lebih cocok untuk mela- kukan migrasi tetapi kemampuan bertelurnya lebih rendah (Denno \& Roderick 1990).

Faktor yang Berpengaruh pada Kelimpahan Brakiptera

Hubungan antara kepadatan nimfa wereng punggung putih pada fase vegetatif maupun generatif tanaman padi tidak nyata baik pada populasi pola pendek maupun pola panjang (Gambar $5)$. 


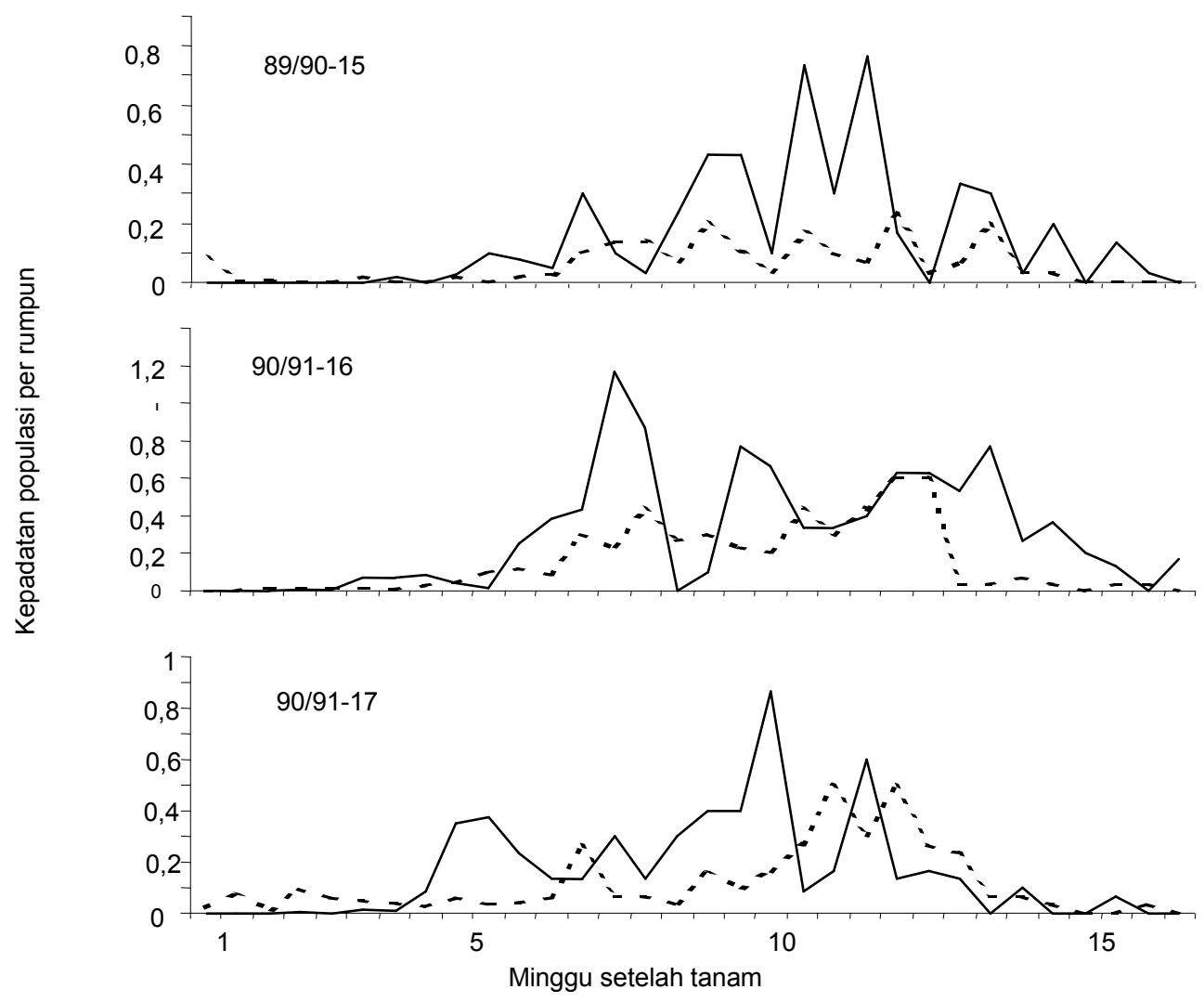

Gambar 2. Fluktuasi populasi imago (garis putus-putus) dan nimfa besar (garis) wereng punggung pada beberapa pengamatan dengan keberadaan populasi yang panjang

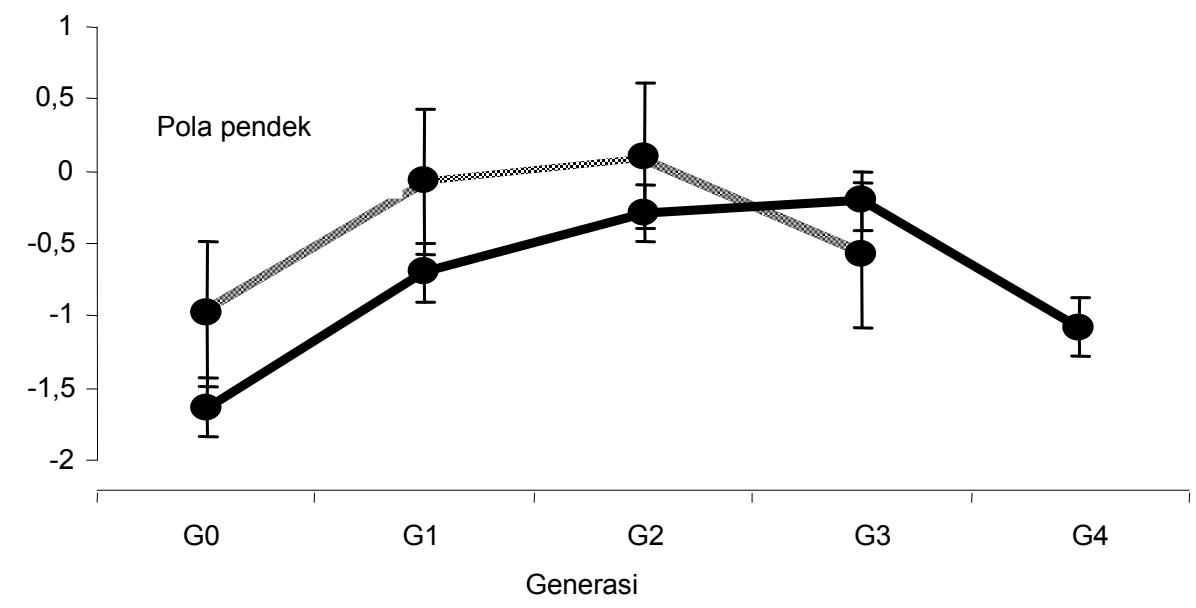

Gambar 3. Pola peningkatan kepadatan populasi musiman wereng punggung putih dari generasi ke generasi (rata-rata \pm 1 S.D) 


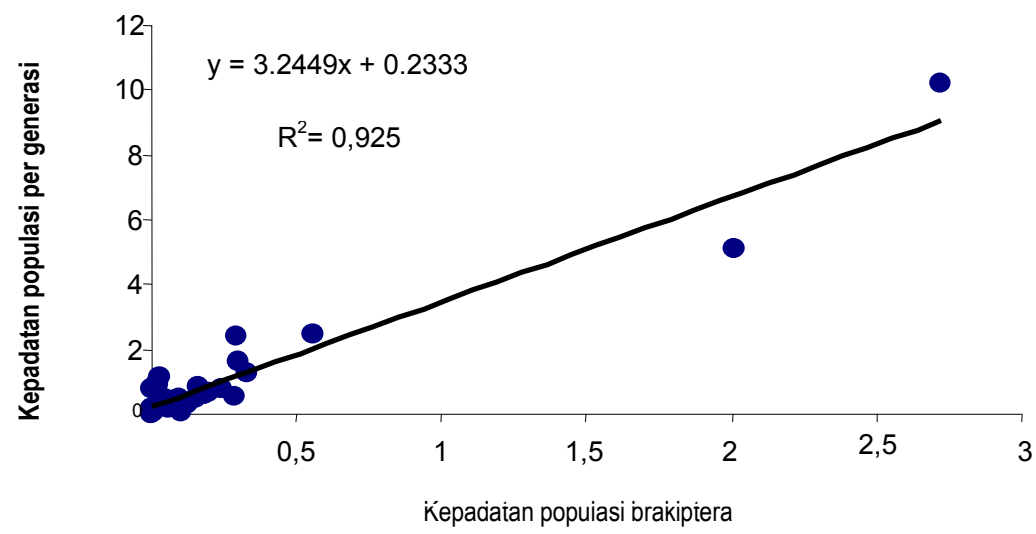

Gambar 4. Hubungan regresi linier antara kepadatan populasi brakiptera dengan kepadatan populasi per generasi wereng punggung putih

Vegetatif (1-7 MST)
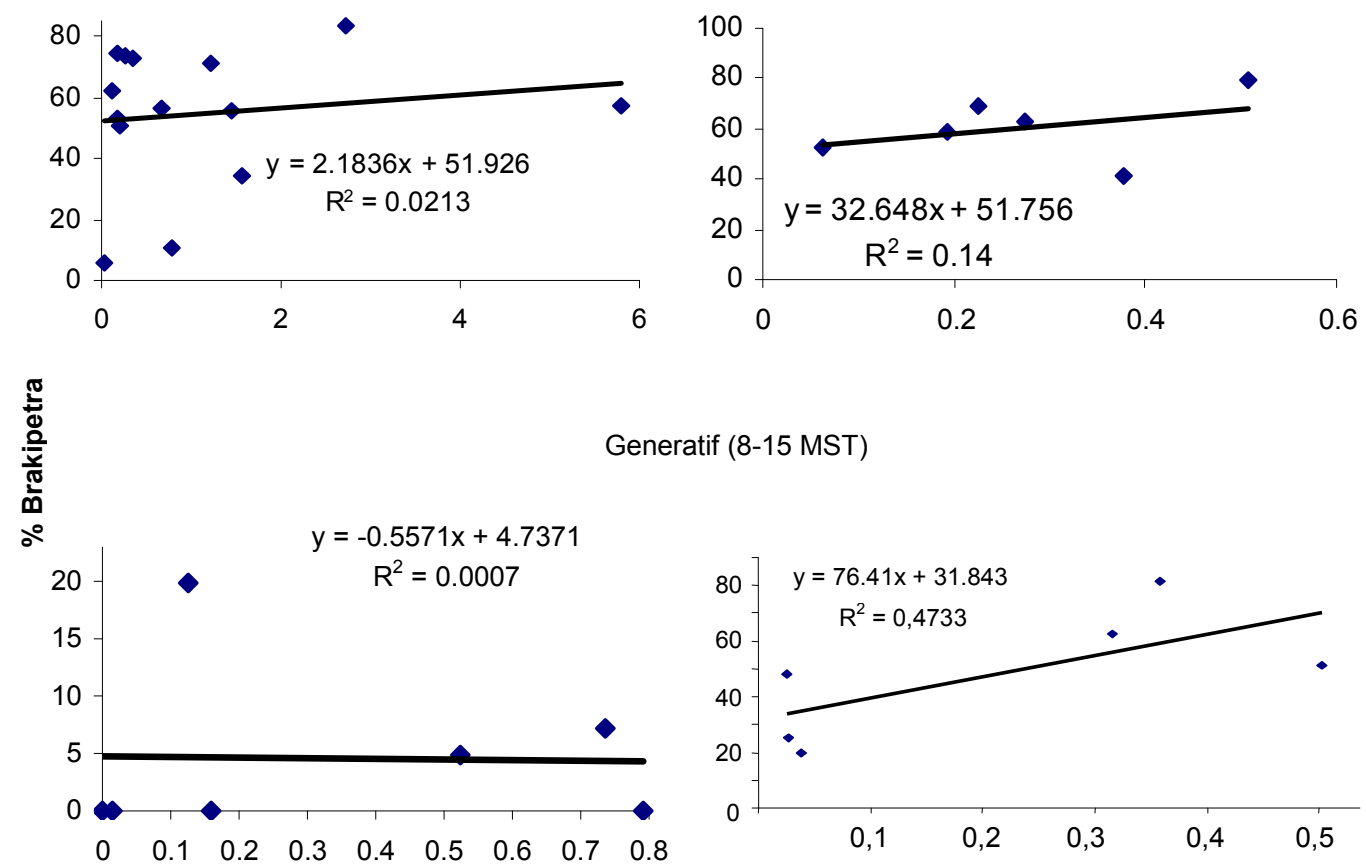

Pola pendek

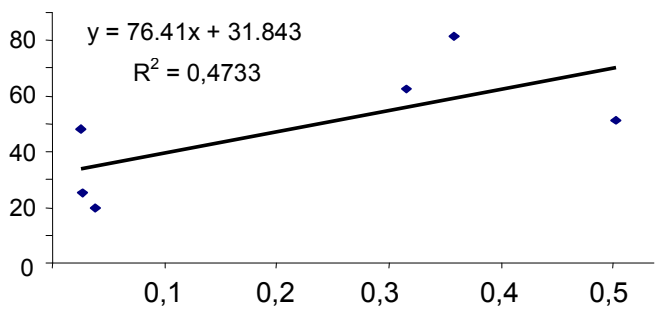

Pola panjang

Kepadatan nimfa besar (log) per rumpun

Gambar 5. Hubungan regresi linier antara kepadatan populasi nimfa dengan proporsi brakiptera pada pola populasi panjang dan pendek saat fase pertumbuhan vegetatif dan generatif tanaman padi 
Pola Pola fluktuasi proporsi brakiptera wereng punggung putih berlawanan dengan pola pertumbuhan kepadatan populasi wereng coklat (Gambar 6) dan sangat jelas terlihat pada pola pendek. Pada populasi pola pendek, kepadatan populasi wereng coklat meningkat dari G1 ke G2 dan dari G2 ke G3. Sebaliknya, proporsi brakiptera wereng punggung putih menurun dari G1 ke G2 dan dari G2 ke G3. Pada pola panjang, proporsi brakiptera wereng punggung putih meningkat dari G1 ke G2 dan dari G2 ke G3.

Hasil analisis regresi antara kepadatan populasi wereng coklat dengan proporsi brakiptera wereng punggung putih menunjukkan adanya hubungan regresi negatif yang nyata $(\mathrm{p}<0,05$; Gambar 7). Hubungan tersebut menunjukkan adanya persaingan antara wereng punggung putih dan wereng coklat. Hasil penelitian ini mendukung hasil percobaan di rumah kaca maupun di lapangan tentang terjadinya kompetisi antara wereng coklat dan wereng punggung putih (Baehaki dan Rifki, 2002). Menurut hasil percobaan mereka, pemenang kompetisi antara kedua spesies bergantung pada nisbah kepadatan populasi awal dan varietas padi yang menjadi inangnya.

Makroptera terbentuk pada kondisi yang kurang menguntungkan sebagai bentuk adaptasi spesies ini untuk berpindah mencari habitat yang lebih menguntungkan seperti kepadatan populasi nimfa yang tinggi (Kishimoto, 1956; Cook \& Perfect 1986), atau umur tanaman padi yang semakin tua (Matsumura 1994). Brakiptera terbentuk pada kondisi habitat yang menguntungkan untuk pertumbuhan populasi, seperti pada kondisi pertumbuhan tanaman yang baik karena dipupuk anorganik (Kajimura et al. 1995). Di samping faktor lingkungan, unsur genetik juga berperan pada terbentuknya dua bentuk sayap wereng punggung putih (Matsumura 1996a). Dari penelitian ini diketahui bahwa di lapangan terjadi kompetisi antara wereng punggung putih dan wereng coklat yang dapat mempengaruhi komposisi dua bentuk sayap dan dinamika populasi wereng punggung putih. 


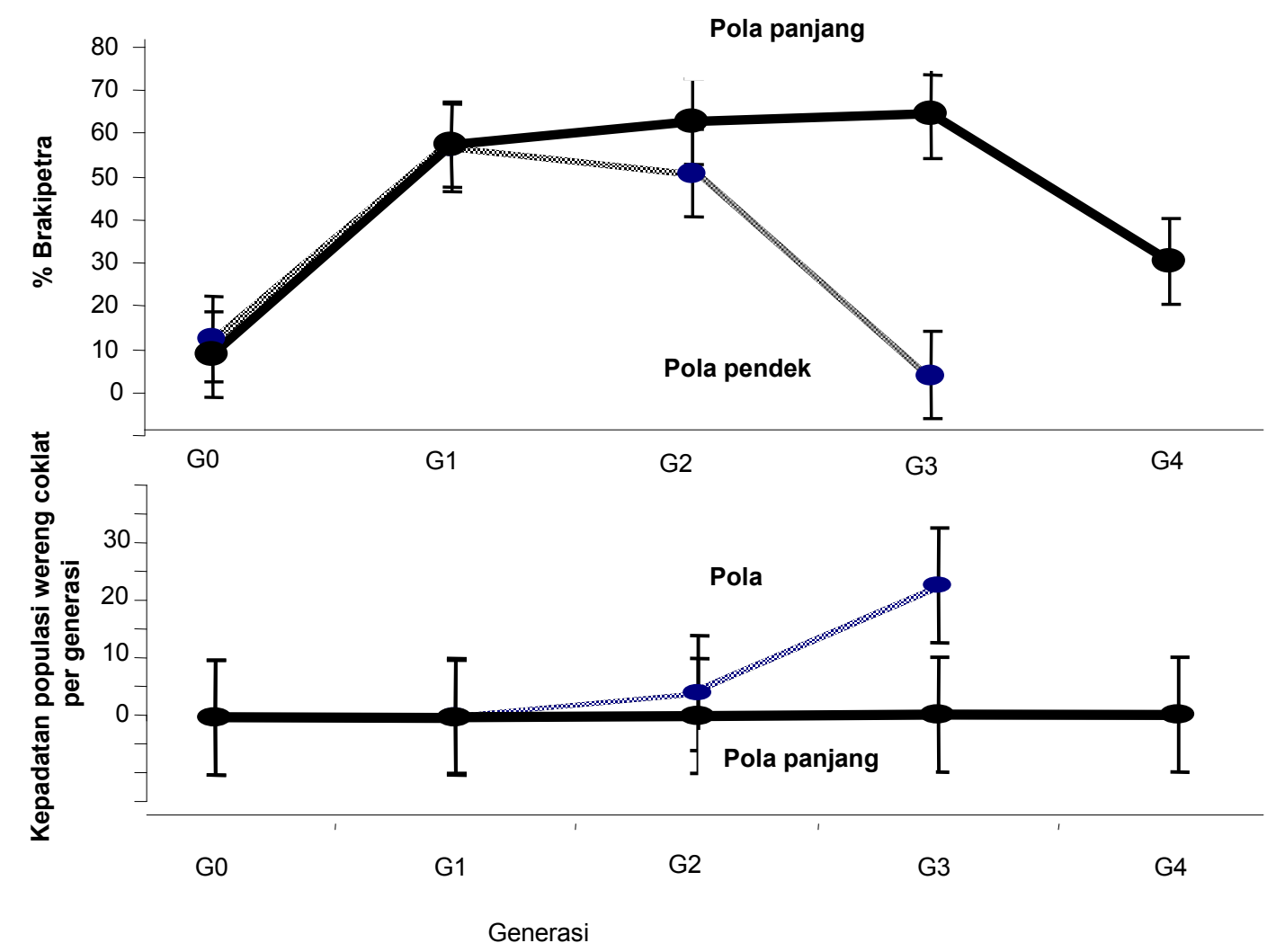

Gambar 6. Perubahan proporsi brakiptera antargenerasi wereng punggung putih (atas) dan perkembangan kepadatan populasi musiman antargenerasi wereng coklat (bawah)

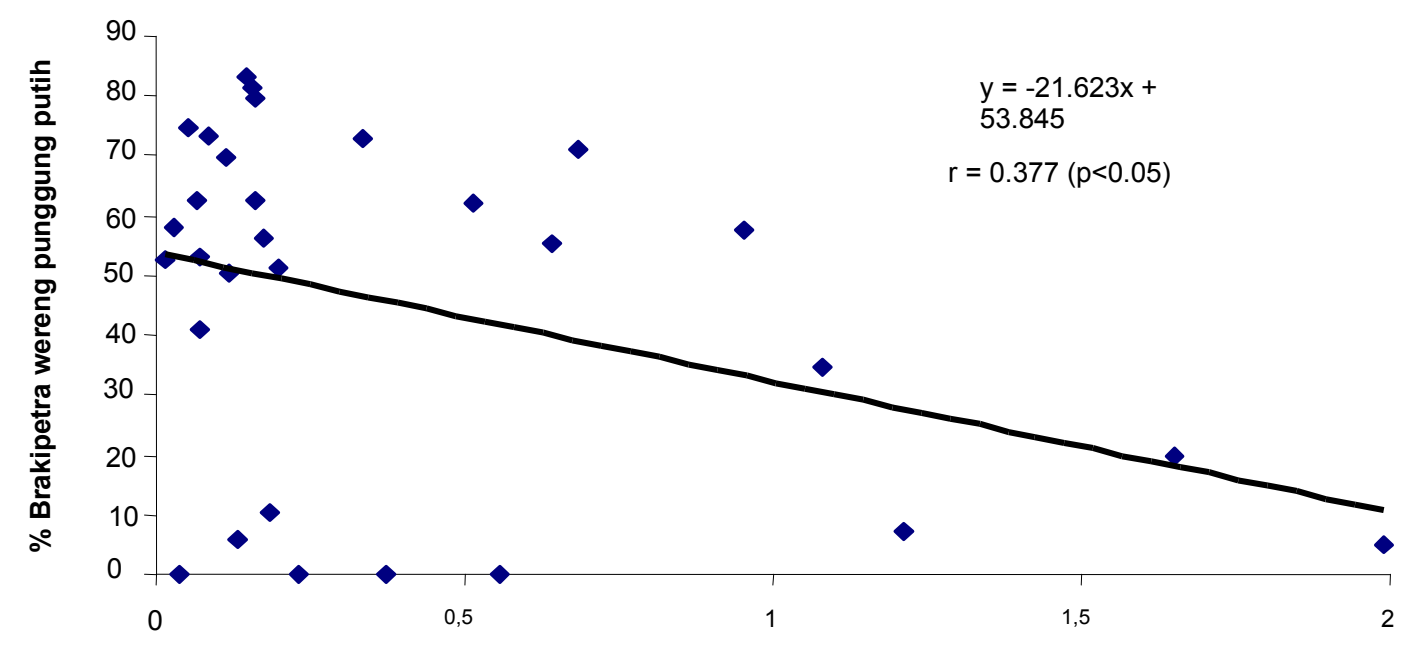

Kepadatan populasi wereng coklat per generasi $(\log n+1)$

Gambar 7. Hubungan regresi linier antara kepadatan populasi wereng coklat dengan proporsi brakiptera wereng punggung putih 


\section{KESIMPULAN}

Serangga imigran wereng punggung putih menginvasi tanaman padi lebih awal dari pada wereng coklat. Pada populasi wereng punggung putih dapat diidentifikasi dua pola pertumbuhan populasi musiman, yaitu pola pertumbuhan populasi pendek, yang dalam satu musim tanam melewati empat generasi, dan pola pertumbuhan populasi panjang yang dalam satu musim tanam melewati lima generasi. Pada pola pertumbuhan populasi pendek, kepadatan populasi meningkat berturut-turut dua generasi setelah immigran datang, sedangkan pada pola pertumbuhan populasi panjang kepadatan populasi meningkat berturutturut tiga generasi, kemudian menurun. Kepadatan populasi brakiptera sangat menentukan kepadatan populasi total. Proporsi brakiptera tidak berkorelasi dengan kepadatan populasi nimfa baik pada fase pertumbuhan vegetatif maupun generatif tanaman padi. Proporsi brakiptera wereng punggung putih mempunyai hubungan regresi linear negatif yang nyata dengan kepadatan populasi wereng coklat. Kompetisi antara wereng punggung putih dengan wereng coklat mempengaruhi proporsi brakiptera dan dinamika populasi wereng punggung putih.

\section{DAFTAR PUSTAKA}

Baehaki SE, A Rifki. 2002. Daya kompetisi wereng coklat dengan wereng punggung putih pada relung ekologi yang sama. Penelitian Pertanian Tanaman Pangan 21: 4153.
Balitpa. 2002. Deskripsi Varietas Unggul 19992002. 43 hal

Carino F0, PE Kenmore, V A Dyck. 1979. The Farmcop suction sampler for hoppers and predator in flooded rice fields. IRRN 4: 21-22.

Cook AG, TJ Perfect. 1986. Seasonal abundance of macropterous Nilaparva lugens and Sogatella furcifera based on presumptive macroptery in fifth-instar nymphs. Ecol. Entomol. 10: 249-258.

Denno RF, GK Roderick. 1990. Population biology of planthopper. Annu. Rev. Entomol. 33: 489-520.

Dyck VA, BC Misra, S Alam, CN Chen, CY Hsien, RS Rejesus. 1979. Ecology of the brown plathopper in the tropics. In Brown Planthopper: Threat to Rice Production in Asia. Los Banos: IRRI. pp.61-98

Kajimura T, IN Widiarta, K Nagai, K Fujisaki, F. Nakasuji. 1995. Effect of organic rice farming on planthopper 4. Reproduction of the whitebacked planthopper, Sogatella furcifera Hovart (Homoptera: Delphacidae). Res. Popul. Ecol. 37: 219-224.

Kuno E. 1968. Studies on the population dynamics of rice leafhopper in a paddy fields. Bulletin of the Kyushu Agricultural Experiment Station 14: 131-246.

Kuno E. 1991. Sampling and analysis of insect population. Annu. Rev. Entomol. 36:285304.

Kishimoto, R. 1956. Studies on the polymorphism the planthopper (Araeopidae, Homoptera). Preliminary report. Oyo-Kontyu 12: 56-61.

Matsumura M. 1991. Chracteristics of recent population growth patterns of the whitebacked planthopper, Sogatella furcifera Hovart in Hokuriku district. Proceeding of the Association for Plant Protection of Hokuriku 39: 47-50.

Matsumura M. 1994. Effect of rice plat stage on wing dimorphism in the whitebacked 
planthopper, Sogatella furcifera Hovart (Homoptera: Delphacidae). Proceeding of the Association for Plant Protection of Hokuriku 42: 54-56.

Matsumura M. 1996a. Genetic analysis of a threshold trait: density-dependent wing dimorphism in Sogatella furcifera Hovart (Homoptera: Delphacidae) the whitebacked planthopper. Heredity 76: 229237.

Matsumura M.1996b. Population dynamics of the whitebacked plathopper, Sogatella furcifera Hovart (Homoptera: Delphacidae) with special reference to the relationship between its population growth and the growth stage of rice plants. Res. Popul. Ecol. 38: 19-25.

Murai T, N Abe, N Oyama, K Sakaiya. 1986. Note on the outbreaks of white-backed planthopper, Sogatella furcifera Hovart and small brown planthopper Laodelphax striatellus Fallen in Aomori prefecture. Annual Report of the Society of Plant Protection of North Japan 37: 131-134.

Oka IN. 1982. The potential to the integration of plant resisatance, agronomic, biological, physical/mechanical techniques and pesticide for pest control in farming systems. Chemrawn II: Pergamon Press.p. 173-184.

Reissig H, HEA Heinrichs, JA Litsinger, K Moody, L Fiedler, TW Mew and AT Barrion. 1986. Illustrated Guides to Integrated Pest Management in Rice in Tropical Asia. Los Banos: IRRI.

Sawada H, A Kusmayadi, SWG. Subroto E. Suwardiwijaya, Mustaghfirin. 1993.
Comparative analysis of population characteristics of the brown planthopper, Nilaparvata lugens Stål, between wet and dry rice cropping season in west Java, Indonesia. Res. Popul. Ecol. 35:113-137.

Sogawa K. 1999. Compound resistance mechanism to whitebacked planthopper in chinese japonica rice variety "Chenjiang 06”. JIRCAS Newsletter 18:4.

Suwarno B. Suprihatno, SN Udin, IN Widiarta. 2002. Panduan Teknis Produksi Benih dan Pengembangan Padi Hibrida. Badan Litbang Pertanian. Jakarta: Deptan. 24 hal

Watanabe T, K Sogawa, Y. Suzuki. 1994. Analysis of yearly fluctuation in the occurrence of migratory rice planthopper, Nilaparvata lugens Stål and Sogatella furcifera Hovart, based on light trap data in Northern Kyushu. Appl. Entomol. and Zool. 38: 7-15.

Widiarta I N. 1995. Hubungan antara kondisi bera dan populasi wereng imigran saat stadia awal pertumbuhan tanaman padi pada sawah tanam serempak. Bul. HPT 8:65-73.

Widiarta IN, Y. Suzuki, H. Sawada, F. Nakasuji . 1990. Population dynamics of the green leafhopper Nephotettix virescens (Distant) (Hemiptera:Cicadellidae) in synchronized and staggered transplanting areas of paddy fields in Indonesia. Res. Popul. Ecol. 32:319328. 